\title{
Industrial land development policy
}

\author{
Catherine Durrant, Ec.D.
}

The industrial/manufacturing sector in the Town of Collingwood, Ontario is a significant contributor to its economy. This paper discusses the sector's historical roots and assesses its current and projected growth to build a case for the proposed industrial land development policy. The author argues that in order for Collingwood to maintain its competitive position for industrial development within the Georgian Triangle Region the policy must be accepted. The paper reasons that addressing the current demand for serviced industrial land will not only strengthen the industrial sector through growth and retention of manufacturing/industry, but will also encourage new growth and opportunities for investment, due to Collingwood's geographic location, available labour force and quality of life.

Keywords: Industrial land development policy, Collingwood, manufacturing

\section{Objective}

The objective of the Industrial Land Development Policy is to maintain a 20 year supply of serviced industrial land to provide sufficient choices of developable land (type, size, price, location) in a competitive market place. All initiatives recommended under this Policy will be fully cost recoverable. Individual projects shall be approved by Council and will be supported by a financial analysis.

Approval will result in the many benefits of increased economic activities, employment and tax revenues. For example, the estimated cost of developing the Sanford Fleming Industrial Park was $\$ 1.2$ million. Currently at 40 per cent build out, the Park generates around $\$ 200,000$ in municipal taxation and \$2.6 million in employment payroll annually.

This Policy will provide a framework for municipal land purchase, site development, application process, applicable uses, industrial permitted uses, zoning provisions and applicable charges.

\section{Introduction}

Collingwood is an 'Industrial Community', with a history rich in industrial development dating back to the mid-1800s. The economic opportunities and the needs of an industrial community change over time. This paper will briefly trace the history of industrial development in Collingwood from early port development in the 1800s to foreign manufacturing investments and local business growth in the later 1900s. The town has prepared an Official Plan to 
accommodate growth from its 1999 estimated population base of 21,497 to a projected 30,357 in the year 2021. 2001 Census population consisted of 16,039 permanent and 3,000 part time residents, growing 2.8 per cent from the 1996 Census figures. The population estimates identified in the Official Plan were slightly higher than the actual Census figures.

The acquisition and development of employment lands in the form of industrial parks is proposed as part of this growth plan. The identification of the costs and benefits associated with this strategy for the town are considered and a draft Industrial Land Development Policy is presented for review and consideration by Collingwood Council.

During the mid to late 1800s, Collingwood was known as the railhead of Ontario and its harbour was the shipment point for goods destined to 'Western Canada'. Shipping produced a need for ship construction and repairs, so it was not long before an organized ship building business was created. In 1883, the Collingwood Shipyards ${ }^{1}$, opened with a special ceremony. The Shipyards became one of the principal industries in the town, employing as much as 10 per cent of the total labour force. The town grew and its needs changed.

\section{Collingwood's industrial revolution}

By 1960s, unemployment was on the rise and a new, active role in industrial development was proposed for the town. The Mayor, Gordon Braniff was approached by a local business man in 1964 regarding the formation of an Industrial Commission for the Town of Collingwood. Funds were not available to hire an Industrial Commissioner, however, the time was right for Council to purchase industrial land and to aggressively attract new industry to Town. Since the Federal Government had declared the Towns of Collingwood, Midland, Meaford and Owen Sound as areas of low employment, Federal funds were allocated to induce the location of new industry to these areas.

The Industrial Commission was formed in 1965 and their first task was to acquire approximately 100 acres of land for an Industrial Park on the east side of Town, with railway access. The properties were sold to firms locating here at approximately $\$ 1,500 /$ acre. The first industry to arrive was TRW Electronics in 1966, followed by the Goodyear Tire and Rubber Company, Barton Distilling Company (now known as Canadian Mist Distillers) and Harding Carpets in 1967. Harding Carpets purchased 50 acres in the west side of town, not requiring rail access for the industry. Also in 1967, Daal Specialities purchased approximately 40 acres of land beside Harding Carpets on High Street and built their facility.

\footnotetext{
${ }^{1}$ The Collingwood Shipyards were originally known as Collingwood Dry Dock Shipbuilding and Foundry Company Limited. Barbara Arp, 1986, Collingwood Reflections, a Historical Anthology - The Industrial Revolution, p. 234.
} 
In 1968, 100 acres next to the east-end Industrial Park were purchased from the Town by Libbey-Owen-Ford-Glass Company on which they built a seven acre plant. The railroad was then extended to their factory.

Through the dedication and persuasion of the Industrial Commission, the Goodall Rubber Company and National Starch and Chemical Company (now Nacan Products), also located their industries in the east end Industrial Park in 1967. Through the strong dedication of this six man Commission, and constant lobbying with the Federal Government, eight industries decided to locate in Collingwood between 1966 and 1970.

In recent decades, through the joint efforts of Council and the Economic Development Department, the Town has successfully developed and marketed several fully serviced Industrial Parks to a diverse range of manufacturing and service industries that today make Collingwood their home. Companies that have established in Collingwood are either locally established entrepreneurial companies, or were established by outside investment as foreign owned companies. Both local and foreign companies have grown successfully in Collingwood. The major manufacturing firms located in town in 2000 are presented in Table 1. The importance of foreign investment to the town is highlighted by 2,213 persons or 83 per cent of Collingwood's manufacturing workforce, being employed in foreign-owned firms.

Table 1. Ownership of Collingwood's manufacturing companies

\begin{tabular}{|l|l|l|}
\hline Company & $\begin{array}{l}\text { Employment } \\
\text { Year 2000 }\end{array}$ & Ownership \\
\hline Goodyear Canada Inc. & 600 & American \\
\hline Alcoa Wheel Products & 596 & American \\
\hline Pilkington Canada Limited & 500 & United Kingdom \\
\hline Backyard Products Ltd. & 210 & American \\
\hline Nacan Products & 110 & American \\
\hline Kaufman of Collingwood & 110 & Canadian \\
\hline VOAC Inc. & 100 & Belgian \\
\hline Goodall Trelleborg Rubber & 54 & Swedish \\
\hline Canadian Mist Distillers & 43 & American \\
\hline Gibralter Springs Water & 42 & Canadian \\
\hline Blue Mountain Pottery & 40 & Canadian \\
\hline T.D. Snow \& Son & 25 & Canadian \\
\hline Sensor Technologies & 21 & Canadian \\
\hline All Others & 199 & \\
\hline Total & $\mathbf{2 , 6 5 0}$ & \\
\hline & & \\
\hline
\end{tabular}


Source: Collingwood Business Directory 2000

The total employment in the listed manufacturing companies is 2,650, almost double the total number of manufacturing employees recorded as Collingwood residents in the 1996 Census $(1,280)$. Labour mobility within the Georgian Triangle is very high. The 1999 report entitled. Manufacturing Sector Strategic Plan for the Town of Collingwood, estimated that 47 per cent of Collingwood's manufacturing workforce is drawn from outside of the Town as the local labour market extends to neighbouring municipalities.

The expected size and needs of Collingwood's future businesses can be identified from the Town of Collingwood's Official Plan, which includes projections to 2021. Both the permanent and recreational populations of Collingwood are expected to grow. The projected population of 30,357 in 2021 would result in an estimated demand for 11,841 housing units, an increase of 3,800 from the 1999 level (Table 2). These additional residential units would require 200 hectares of land, while the growth in employment to support this larger population would require an additional 63 hectares for business development (Table 3).

Table 2. Population/housing unit projections

\begin{tabular}{|l|l|l|}
\hline YEAR & POPULATION & HOUSING UNITS \\
\hline Mid-1991 & $\mathbf{2 0 , 0 0 0}$ & $\mathbf{7 , 4 1 5}$ \\
\hline Mid-1996 & $\mathbf{2 0 , 8 0 5}$ & $\mathbf{7 , 8 2 1}$ \\
\hline Early 1999 & $\mathbf{2 1 , 4 9 7}$ & $\mathbf{8 , 1 4 1}$ \\
\hline Early 2009 & $\mathbf{2 4 , 8 3 8}$ & $\mathbf{9 , 5 9 1}$ \\
\hline Late 2021 & $\mathbf{3 0 , 3 5 7}$ & $\mathbf{1 1 , 8 4 1}$ \\
\hline
\end{tabular}

Table 3. Land needs projections

\begin{tabular}{|l|l|l|l|l|l|l|l|l|}
\hline \multirow{2}{*}{ Planning Interval } & \multicolumn{4}{|l|}{ Residential Land Need } & \multicolumn{2}{l|}{$\begin{array}{l}\text { Industrial Land } \\
\text { Need }\end{array}$} \\
\cline { 2 - 8 } & \multicolumn{2}{|l|}{ Single/Semis } & \multicolumn{2}{|l|}{ Multiples } & \multicolumn{2}{|l|}{ Apartments } & \multicolumn{2}{l|}{} \\
\hline & Units & Ha & Units & Ha & Units & Ha & $\begin{array}{l}\text { GFA } \\
\text { (sq.m.) }\end{array}$ & $\begin{array}{l}\text { Land } \\
\text { Area } \\
\text { (Ha) }\end{array}$ \\
\hline $\begin{array}{l}1999 \text { to 2009 } \\
\text { Projection }\end{array}$ & 817 & 69 & 488 & 10 & 145 & 1.5 & 56,000 & 26 \\
\hline $\begin{array}{l}1999 \text { to 2021 } \\
\text { Projection }\end{array}$ & 2081 & 175 & 1249 & 25 & 370 & 3.7 & 135,000 & 63 \\
\hline
\end{tabular}




\section{Industrial design lands}

The Industrial designations on the Schedule 'A' Land Use Plan, are intended for employment generating uses, which are accommodated in relatively low profile building forms.

Traditional uses in land designated as Industrial have been primarily manufacturing, warehousing and transportation. New forms of business opportunities are emerging in the form of computer processing, film and communications, publishing and printing, all of which can be appropriately located in Industrial designation zones.

In order to maintain the stability of Industrial designations within the Town of Collingwood, incompatible non-industrial uses are restricted from locating on Industrial designations. There are weights for intensification that can be directed towards the appropriate locations by accommodating limited office and service commercial uses on peripheral Industrial sites, located on arterial roads. The increased traffic can be readily accommodated and the interior Industrial designations can be maintained for traditional and new forms of industrial employment.

Despite the Town of Collingwood's efforts to retain Industry, some industries may close or relocate, creating pressure for redesignation and redevelopment to non-industrial uses.

Consideration of such proposals shall be in accordance with the Amendments to delete industrial designations Section.

\section{Current industrial parks}

The following Industrial Business Parks represent the major industrial areas in Collingwood:

\section{Sanford Fleming}

The newest of Collingwood's industrial parks, consists of 50 acres and was purchased by the Town of Collingwood from LOF Glass in 1985. This park is a fully developed and serviced municipal industrial park, zoned M1 and is home to a range of medium to heavy industry. The park abuts the railway and an initiative is currently underway with the Ministry of Agriculture and Food to implement a truck to rail facility in the five remaining acres in the park that abut the railway, in an attempt to provide industry in Collingwood, as well as the surrounding area, easy access to rail service, thereby providing economical transportation options.

\section{Stewart road business park}

This Business Park consists of around 30 acres, is about 20 years old, serviced and was an initiative of the private sector. Several vacant lots, owned by the private sector are available for 
development. This area is zoned M1, and is home to a number of diversified companies from high-tech to heavy industry, that employ many members of our local labour force and make a direct contribution to our taxation base.

\section{East end industrial park}

A fully developed 100 acre industrial area, located to the east of the central business district., currently accommodates a range of heavy industry zoned M1, that contribute to the Town's economic base through taxation and employment revenue.

\section{West end industrial park}

200 acres - a built up industrial area, located to the west of the central business district, accommodates several 'heavy' industries zoned M1, making a contribution to the City's economic base through taxation, employment revenue and business spin-offs.

\section{Future options}

The consumption of industrial land is quickly outstripping the supply of serviced land. All economic indications are for a strong economy and therefore demand for new and expanded industrial facilities will continue in the short and long term. These indicators are:

- Collingwood is experiencing spin off relocations from the Greater Toronto Area (GTA), due to that area's high housing prices, increased traffic congestion and travel times; high land prices and an increasing concern for an improved quality of life for employers, labour force and their families. (Town of Collingwood, Economic Development Department, Building Department - annual list of building permits).

- Existing businesses will account for as much as 90 per cent of economic growth in the community. They deserve priority attention in an economic development program. (Town of Collingwood, Collingwood Economic Development Strategy, 2001).

- 70 per cent to 85 per cent of new Foreign Investment is follow-on investment by MultiNational Enterprises (MNE's), already established in Canada. Foreign-owned subsidiaries in the community should be the primary focus of an international business attraction program. (Town of Collingwood, Collingwood Economic Development Strategy, 2001).

- It is estimated that a new supply of serviced industrial land is required to provide a sufficient choice of location; size; type of development; owned vs. leased and zoning to maintain a competitive price market. Presently land prices are increasing rapidly. Collingwood's limited supply/price choice is resulting in a loss of business investment and opportunities for re-locations to the area. This situation will worsen without further servicing of industrial land in the immediate future. 


\section{Rationale}

To maintain the Town of Collingwood's competitive position for industrial development within the Georgian Triangle Region., the municipality must adopt the $3-5$ year strategy proposed by the Economic Development Department:

- Acquire and develop lands suitable for industrial development. Begin negotiations to purchase the industrial lands if possible, $125+/$ - acres, adjacent to Sanford Fleming Industrial Park in the east end of Collingwood;

- Begin servicing of lands in cooperation with the private sector;

- Upgrade and/or extend services in existing industrial areas to encourage further development.

The approval of an Industrial Land Development Policy as a 2003 Corporate Priority will provide the first steps in the required process to commence implementation of this strategy.

New municipally owned industrial park

'If we don't build it, they won't come'. Currently Collingwood does not have any available municipally owned industrial land for sale and development. There are about five acres of privately owned industrial land available within the municipality, however the price established by the private sector is prohibitive and discourages development. The Economic Development Department has worked aggressively with Engineers and Land Surveyors in an attempt to assemble agricultural lands currently zoned agricultural but designated industrial in our new Official Plan, in an attempt to address the current and future needs of the industrial sector through growth and retention, attracting employment and new residents to the community. The Council of the municipality is in favour of the purchase of additional municipal industrial lands to address growth and employment initiatives within the community.

The lands being considered for development consist of two separate parcels comprising a total area of approximately 125 acres, adjacent to Sanford Fleming Industrial Park in the east end of Collingwood.

This new municipally owned Industrial Park will include approximately $2.5 \mathrm{~km}$ of internal roads and 45 industrial lots, each having an average area in the order of 1.25 ha (3.0 acres), recognizing that multiple lots can be combined to suit the needs of potential industry. Currently the development concept is very preliminary and will require significant modification to properly address servicing and storm water management constraints. 
In addressing infrastructure concerns relative to sustaining and building upon Collingwood's economic growth; water, electricity and natural gas are adequate both in capacity and quality to accommodate anticipated growth in Industrial Development.

Sewage treatment capacity in Collingwood appears to be adequate to accommodate additional growth. However as a result of the Town accepting the discharge of processed water from a high volume manufacturer in the eastern end of the municipality, the sewage trunk system in that area needs to be expanded to accommodate additional industrial development.

Of more immediate concern is the adequacy of the supply of Industrial land in Collingwood. The total inventory of serviced industrial land is approximately 20 acres. Based on recent growth rates, land supply and adequacy of the municipal infrastructure serving this area, will be a limiting factor in Collingwood's future economic development

The proposed new Industrial land will be developed in two stages for economic reasons. Servicing the area is expected to be completed in two phases, addressing the additional industrial land requirements as identified in the Town of Collingwood's Official Plan. This area will address the growth and retention of Collingwood's industrial sector.

\section{Projected costs}

Land

$\$ 500,000.00$

Servicing (Road, Water,

$\begin{array}{ll}\text { Sanitary, Storm water) } & \$ 3.210,000.00 \\ \text { Hydro } & \$ 500,000.00 \\ \text { Engineering } & \$ 300,000.00\end{array}$

(Source: C.C. Tatham \& Associates Ltd.)

The total projected costs will be approximately $\$ 4.5$ million dollars. Allowing for contingencies and taxes, the projected price for land sales will be around $\$ 50,000 /$ acre. This price is competitive with neighbouring municipalities.

\section{Labour force}

Collingwood is the centre of a larger economic region called the Georgian Triangle, and services an area in excess of 74,000 permanent residents. The economies of the communities in the region are closely intertwined. Labour mobility within the region is very high, providing a labour pool of approximately 40,000 residents. Approximately 50 per cent of the employees of Collingwood's manufacturing firms reside in other Georgian Triangle communities. Likewise, 
26 per cent of Collingwood's residents leave the Town each morning for work, elsewhere in the Region (Census, 2001).

\section{Process to purchase municipally-owned industrial land}

\section{Approval procedure}

Municipally owned and developed industrial land is available on a serviced and rough-graded basis. The purchasing procedure is very simple, taking between three to six weeks, as outlined below. The Economic Development Office is the coordinating department for all municipally owned industrial land sales.

Deposit

- A deposit of 5 per cent of the purchase price is required for an 'Offer to Purchase' (minimum $\$ 5,000$ ), to be presented to City Council, the final decision-maker.

The agreement

- The Offer to Purchase is prepared by the Town's Solicitor at the Town's expense. Upon receipt of a 5 per cent deposit, the Agreement is prepared.

Council approval

- Town Council approval of a land sale is done through a Resolution and the passing of a by-law, which requires a majority Council vote. Normally, Staff presents Council with a Signed Offer and accompanying Staff Report. Closing date after Council acceptance is normally 60 days or less.

\section{Performance clauses}

Purchasers of Town-developed industrial land may be required to fulfill certain conditions within a set time period after taking title to the land. Some of the standard conditions are:

\section{Construction start and completion date}

- Construction start is required within one year of the purchase date. Construction is to finish within one year of the construction start date.

Minimum building coverage 
- The minimum building coverage requirement is recommended at 20 per cent of the total land area. The maximum building coverage, as controlled through the zoning by-law regulations is approximately 50 per cent although; this figure may be reduced due to storm water management design parameters.

\section{Penalty}

- Should the purchaser fail to comply with the conditions above, the Town has the option of repurchasing the land at 90 per cent of the original purchase price.

- If an extension of time to complete construction is granted, Council may request the Purchaser to pay to the Town, by way of liquidated damages.

1. An amount equal to the amount of municipal taxes, which the Purchaser would have been required to pay had a building or buildings been constructed as above required;

2. Any increase in value of lands during the period of the extension.

Right of first refusal

- The Purchaser covenants that they will not sell the lands without first offering it to the Town at the original purchase price.

Real estate commission

The Economic Development Office, requests that in order to qualify for a commission, any involvement by a real estate broker or his agent must be registered in the office of Economic Development. In order to achieve the appropriate registration, it is required that the following procedures are completed:

- To register the client, the Economic Development Office must receive a Client Registration Form as provided by the Economic Development Office, or have the client personally introduced by the Realtor.

- The Client Registration Form (CRF) is paramount. The most recent CRF for a specific land sale will be the one used by the Economic Development Office for allocating commission's payable.

- All Client Registration Forms received will have a termination period of 90 days, unless otherwise agreed upon by the Economic Development Office.

- Provided that an agent or broker has properly registered a client with the Economic Development Office, the Town of Collingwood agrees to pay a commission based on 5 per cent of the total sale price of the land. 
- Should an agent or broker refer an industrial client to the Economic Development Office, and prefer not to get directly involved with the sale, the staff of the Economic Development Office shall register the referral and the Town of Collingwood will pay a 1 per cent referral fee in the event of a sale.

\section{Site planning process}

\section{Site plan control}

Site Plan Control is applied to all new and expanding Non-Residential buildings in Collingwood. The procedure requires that Site Plan drawings (and in some cases, elevation and cross-section drawings), be approved by the Town and that a Site Plan Control Agreement be signed by the property owner before a building permit can be issued.

The Planning and Development Department co-ordinates all Site Plan Control procedures. The overall appraisal of the project takes into consideration comments from internal Town Departments, Provincial Government Departments, Conservation Authorities, County of Simcoe and special purpose bodies where applicable. Their comments, usually available within a twoweek period, generally address the aesthetic and functional relationships with adjoining public and private properties.

\section{Site plan application: Fee and requirements}

- The Site Plan Application Fee is a minimum of $\$ 1,000.00$;

- A complete submission must include an overall Site Plan, a Landscape Plan and a Lot Grading/Drainage and Servicing Plan. Fifteen (15) sets are to be submitted;

- Building Elevation Drawings are required for purchasers of Town-owned industrial land;

- A Site Plan Control Agreement is required and security for 100 per cent of the cost of site works is required to be submitted to the Town, and may be in the form of a Letter of Credit. The Site Plan Control Agreement and security must be in place prior to a building permit being issued.

The site plan

To facilitate the Site Plan appraisal, the Town requires that Site Plan drawings include information, on the building, grading, servicing, and landscaping. The following details should be included on the Plans submitted.

The Site Plan drawings should include a symbol key with legend and the following information and requirements (clearly show what is existing and what is proposed): 
- North area; standard scale, preferably in metric;

- The dimensions of the site as taken from a survey or legal description of the property; street name;

- The location and use of all existing and proposed buildings and structures on the site (future buildings should not be shown);

- Finished floor elevations of buildings;

- Location of closest fire hydrant (existing or proposed);

- Designated fire routes;

- Maximum dimensions of buildings; minimum distance between buildings;

- Travelled portions of roadways, access driveways, and parking area layout, ramps (all showing minimum dimensions or typical dimensions and surface material);

- Location of any walkways, stairs, building entrances;

- Amenity areas;

- Location, height and type of all proposed fencing and curbing;

- Location of all existing and proposed poles, transformers, hydrants and sidewalks on the site and on public lands abutting the site;

- Exterior lighting location, design, colour and throw;

- Location of all existing and proposed easements and rights-of-way;

- Location and type of enclosure to be used for storage of garbage and other waste material;

- Location of any lands to be dedicated for public purposes;

- Setbacks of structures (buildings, signs, parking) from property lines in all cases;

- Total existing and proposed building size in square feet/square meters; lot area; total number of parking stalls; total number of units;

- State whether the building is to be sprinklered or not sprinklered. Show location of Fire Department connections.

\section{Grading and servicing plan}

The Grading/Servicing drawings should include the following information; symbol key and legend (clearly show what is existing and proposed):

- Existing and proposed grade elevations;

- Existing services (storm, water, sanitary, hydro, fiber optics, gas);

- Location, size and depth of cover of storm, water and sanitary services; manholes;

- Statement if existing services is to be used or if services are proposed;

- Direction of surface drainage flow through use of drainage arrows;

- Proposed and existing structures and buildings;

- If catch basins are to be used, show proposed storm sewer hookups and storm laterals size and location; catch basin rim elevation; 
- If storm water management design is required, state maximum detention time of pond, maximum flow and maximum storage volume for a 5 and 100 year return period storm;

- Existing and proposed driveway entrances and curbs;

- Type of surfacing (sod, gravel, asphalt, etc.);

- Relative street grade elevations fronting site; property lines;

- Swales and drainage ditches (indicate slope and side slopes and, where required, crosssections);

- Elevations of individual internal driveways where a depressed driveway may exist. Note: Drainage must remain internal to the site unless approved by the Town of Collingwood, Engineering and Public Works Department;

- Location of nearest fire hydrant - existing and proposed;

- Location of existing and proposed siamese or standpipe connections;

- Hydro poles and transformers;

- Invert of storm, sewer and water laterals at point of connection;

- Location of existing and proposed easements and rights-of-way road dedications;

- Location of any lands to be dedicated for public purposes;

- When a new storm sewer, sanitary sewer or waterline connection to the site is required, the location of the new facility and the respective main lines which serve the site shall be shown complete with size, slope and elevation of all services both existing and proposed;

- When drainage patterns either on the site or external to the site will be influenced, the following shall be shown:

Existing Elevations:

1. at intervals of no more than $15 \mathrm{~m}$ on the periphery of the site;

2. on a maximum of $15 \mathrm{~m}$ grid throughout the site;

3. and at any existing buildings within $15 \mathrm{~m}$ of the site;

Proposed Elevations:

1. at all buildings, curbs, catch basins, ditches or pertinent drainage features;

2. at location as required to clearly illustrate drainage paths and conformity with adjacent properties.(All measurements shall be in standard metric units.)

\section{Landscape plan}

The provision of a separate Landscape Plan is a requirement of the Site Planning Process. It is highly recommended that a Landscape Architect be used to assist with this task. When drafting and implementing the Landscape Plan, staff suggest the following guidelines are adhered to:

1. A variety in the shape, form and colour of plant material.

2. Landscape detail should strongly focus on front yards, site entrances, large parking areas and loading docks. 
3. The majority of landscape material selected should be coniferous for year round appearance and minimal maintenance.

4. Entire site should be landscaped with any surplus topsoil being removed.

Landscape drawings should show a legend with key symbol and the following information:

- Existing and proposed buildings;

- Location of existing plant material to remain;

- Location of vegetation to be removed;

- Location of all proposed plant material, planting beds and seeded or sod areas;

- Plant List showing key, numbers of plants, botanical and common names and plant size at installation date;

- Location of pathways, play areas, special activity areas, open space areas, building entrances and doorways;

- Location and treatment of garbage collection areas;

- Existing and proposed curbing, sidewalks, and hard surface areas;

- Location, height and type of proposed and existing fencing.

\section{Industrial zoning by-law 03-38}

\section{3-38.1: Regulation applicable in all industrial use class zones}

1. Offices in Industrial Zones: The office floor area required by an industrial use, for its own executive and administrative purposes or to accommodate in-house technical and professional services may be located:

- In the same building as the industrial use;

- In a separate building on the same lot as the building occupied by such industrial use, provided that all buildings on the same lot are held in single ownership or by participants in a condominium corporation or cooperative;

- In an industrial mall;

- In an office building permitted in an M1 zone;

- In a trailer located on the same lot and situated on such lot for the purposes of providing office accommodation for an industrial use, shall be considered as temporary use, pending the completion of construction of permanent office accommodation within a building on the lot.

2. Location and Screening of Outdoor Storage Areas:

a) Subject to clause (b), no outdoor storage of equipment, goods and materials shall be provided in any M1-Class zone. 
- Between the street line and regulatory building line and, if provided between the regulatory building line, and established building line, shall be screened from view along the regulatory building line;

- Within the minimum exterior side yard required by this by-law and if provided in any part of an exterior side yard, which is greater than the minimum required by this bylaw, shall be screened from view along the line of the exterior side yard required by this by-law.

b) Any outdoor storage of equipment, goods or materials in an M1 zone shall be screened from view by one or any combination of a solid fence or wall or each berm not less than 2.5 meters in height erected around the entire perimeter of the outside storage area.

3. Use of Vacant Industrial Lands for Non-Industrial Purposes:

Notwithstanding the provisions of this by-law, vacant lands in any industrial use class zone may be used for one or more of the following purposes provided that no building or structure is erected, located or used in conjunction therewith:

- Market gardening;

- Landscape gardening;

- Non-commercial recreational use.

\section{3-38.2 Industrial permitted uses}

Primary uses in Industrial designations, shown on Schedule A, Land Use Plan, shall include manufacturing, warehousing, wholesale, research and training facilities, computer data operations, film and communications, publishing and printing, business services, transportation uses including truck and rail terminals, public works depots and contractors yards, servicing and repairs, electric power facilities, certain automotive service establishments such as body shops which are not permitted in commercial or residential areas and similar employment activities. In addition, large scale recreational and entertainment uses such as fitness clubs, banquet halls and arenas. Offices, showrooms, open storage and caretaker dwellings are permitted as ancillary uses.

\section{Retention of industrial land}

In order to retain Industrial lands the Town of Collingwood shall support the re-use of vacant or under-utilized industrial lands for industry wherever possible. Where appropriate, the adaptive re-use of vacant industrial buildings for alternative employment activities will be supported, provided no unacceptable impacts are created on adjacent industrial operations. 
Any proposal to add or enlarge an Industrial designation shall be evaluated on the basis of:

- The impact on the compatibility with the land surrounding the subject land use;

- viability of the remainder of the lands to be left in their current designation to be used for that designated purpose;

- The adequacy of the transportation network, particularly the local road system to accommodate additional traffic volumes.

\section{Zoning provisions}

The Zoning Code shall provide detailed permitted uses and may further divide the Industrial designation into categories based on a range of permitted uses.

The development or redevelopment of Industrially designated lands which are adjacent to Residential designations shall reduce potential land use conflicts through limitations on permitted uses, building and design, setbacks and buffer areas, controls on noise and air pollution, vibrations and the location of garbage handling facilities, loading docks, open storage parking areas and exterior lighting.

\section{Amendments to delete industrial designations}

As it is the Town of Collingwood's intention to retain industrial designations for employment generating uses wherever possible. Applications to amend the Official Plan for non-industrial uses may only be considered if:

- Council is satisfied that the site is not feasible for use by industry over the long term;

- The redesignation would not represent an intrusion into an Industrial area which is likely to foster similar redesignation applications on adjacent lands;

- The remaining industrial land in the vicinity can still function as a viable Industrial area.

\section{Industrial business parks}

\section{Industrial business parks uses}

1. A general industrial use M1 as described in 03-38.2 where no outdoor storage is provided and all operations are conducted within wholly enclosed buildings, but not to include a motor vehicle repair shop, or auto body repair shop, and auto service mall, an establishment for display, sales and service of motor vehicles and motorized equipment, a bonded customs warehouse or a courier or delivery service;

2. An office building having at least $\mathbf{1 , 6 0 0 \mathrm { m } ^ { 2 }}$ of gross floor area provided for occupancy by one or more of the following uses: 
a) printing, publishing or broadcasting facilities;

b) a data services establishment;

c) a food services establishment which occupies not more than $\mathbf{5 0 0} \mathbf{~ m}^{\mathbf{2}}$ of the gross floor area of the building and which is not freestanding on the site;

d) the offices of a professional consultant providing management, architectural, engineering, town planning, land surveying, market research, industrial design or interior design;

e) a call centre;

f) the executive and/or administrative or business offices of one or more of the following:

- An industrial enterprise whose industrial activities may be conducted off-site elsewhere but not necessarily within the Town of Collingwood.

- A retail/wholesale business in which no sales are offered on site.

- A service industry specifically limited to construction, transportation, communication and utilities uses.

\section{General industrial uses (M1)}

1. The manufacture, processing, production, fabrication, packaging, assembly, sub-assembly, stamping, treating, finishing, refining, distilling, testing, warehousing, including a bonded customs warehouse, storage and stockpiling of products, goods, materials, patterns, tools and dies, but does not include an impounding yard, asphalt or concrete plant, building contractors yard, a wrecker's or salvage yard or junk yard;

2. A computer programming, data processing or other data services establishment; an establishment for the development of an/or instruction in, computer assisted design and computer assisted manufacturing;

3. An establishment for the development of telecommunications or other advanced technology equipment, processes or programs;

4. Industrial research and development;

5. Laboratory for quality control or product development;

6. Printing or publishing establishment;

7. Caterer's establishment;

8. Lumberyard in conjunction with which an establishment for the storage and sale of home improvement supplies may also be provided as an accessory use; establishment, but not a contractor's yard or a retail sales office; 
9. A courier or delivery service depot;

10. A health club/fitness club (training and recreational facility);

11. Offices of a professional consultant ie: architectural, engineering, land surveying, management, research;

12. Satellite office for any industry, not necessarily located in the Town of Collingwood;

13. Arena or community centre, broadcasting \& communications, bulk storage, cartage, transport and/or rail depot, custom workshop, equipment, sales and rental, heavy, farm implement sales establishment, laundry or dry cleaning plant - not retail, machine or welding shop, manufacturing, processing, assembly or fabrication plant, heavy and light;

14. Motor vehicle body shop, motor vehicle service station, motor vehicle supply outlet parking lot, retail lumber and building supply outlet, outside storage, concealed outside storage, outside display and sales storage, wholly enclosed or warehouse storage, water pollution control plant, water treatment plant;

15. Training facilities for industrial trades;

16. Rental establishment of materials;

17. A public beverage making establishment;

18. A recording studio;

19. A security or janitorial service.

\section{Development charges}

Any industry contemplating a plant expansion or the construction of a new facility should be aware that development charges will be calculated on the total area of the new construction space at .28 cents/square foot, which is the education levy. This development charge is current and not subject to change, without a Resolution from Council. 


\section{Property taxes}

In the Province of Ontario, property taxes are collected based on a percentage of the assessed property value. The rates differ depending on the property type. Every municipality in Ontario is required to collect property taxes, and set the tax rates for the various property types.

Tax revenues in the Town of Collingwood for selected property types are

$\begin{array}{llr}\text { Residential: } & 69 \text { per cent } & (\$ 19,163,163) \\ \text { Commercial } & 22 \text { per cent } & (\$ 6,022,395) \\ \text { Industrial } & 9 \text { per cent } & (\$ 2,458,470)\end{array}$

Total Revenues: $\quad \$ 27,644,028$

\section{Financial impact}

The 2003 Capital Budget Projections as approved by Council on June 2, 2003, included $\$ 4.5$ million for a new Truck Line to service the east end of Collingwood, and \$500,000 Capital for industrial land purchases. The provisions for future development within this sector will be dealt with by the incoming Council during the 2004 Budget deliberations.

\section{Conclusion}

The Industrial/Manufacturing sector is and will continue to be a significant contributor to Collingwood's economy. Most notably, this sector boasts a strong commitment from foreign investors. Industries that have remained and thrived in Collingwood have made the transition from labour intensive companies manufacturing product for the domestic market, to firms that are specialized and capital/technology intensive, manufacturing product for both the domestic and export markets. Location and transportation are critical to the success of these companies especially with Just-In-Time manufacturing systems having been adopted as the new industry standard.

Collingwood's strategic location enables local companies to have quick access to both Canadian and U.S. markets. In excess of 250 million consumers are within a two to 12 hour drive of the Town of Collingwood. Additionally, companies in the $21^{\text {st }}$ century simply cannot be burdened with an uncompetitive cost environment or their comparative advantage is lost. Cost competitiveness is an essential element for stability and growth of the local manufacturing economy. 
The continued demand for serviced industrial land will not only strengthen this sector through growth and retention of manufacturing/industry, but will encourage new growth and opportunities for investment, due to Collingwood's geographic location, available labour force and quality of life.

As economic activity continues to spur industrial development, the quality of services insisted upon by the Town will result in an improved neighbourhood image, and a higher quality environment befitting Collingwood. The site development guidelines that have been recommended, land purchasing policy and zoning, are all suggested as tools to ensure that the manufacturing/industrial sector develops in an attractive manner, raising the quality of life both for the employer and the residents of Collingwood.

\section{Author Biography}

Catharine Durrant is the Economic Development Officer for the Town of Collingwood, a position she has held for the past four years. Catherine has been with the municipality for 19 years, working in both the Mayor's Office and Economic Development as Co-ordinator. Currently she is responsible for all aspects of Economic Development within the Town of Collingwood consisting of Strategic Economic Planning, Industrial Development, Land Sales and Projections, Economic Impact Analysis, Labour Force, Marketing, Promotions and Tourism. She is a Director on the Georgian Triangle Tourist Corporation, Housing Resource Centre and Chamber of Commerce. Catherine has held positions in Marketing Research and Financial Brokerage in Toronto, prior to settling in Collingwood. Her Post-Secondary Education is in Business and Public Administration from Fanshawe College, York University and St. Lawrence College. She has a Diploma in Economic Development from the University of Waterloo and received her Ec.D., in 2002.

\section{References}

Advisory Services/GPA. (1999). Manufacturing Sector Strategic Plan for the Town of Collingwood.

Ainley \& Associates. (2000). Consulting Engineers and Planners, Town of Collingwood 2000 Official Plan Amendment May 2002, Page 10, currently pending approval from the County of Simcoe.

Arp, Barbara. (1986). Collingwood Museum - Reflections 1986 - The Industrial Revolution Collingwood - An Historical Anthology.

City of Toronto - Economic Development Department, communication. 
City of Ottawa - Economic Development Department, communication.

Ontario Planning Act - Section 41.

Statistics Canada. (1996). Census data.

Statistics Canada. (2001). Census data.

Town of Collingwood. (2002). Collingwood Business Directory 2002.

Town of Collingwood. (2001). Economic Development Strategy 2001. 